\title{
EFFECT OF WORK-FAMILY CONFLICT, JOB STRESS AND ORGANIZATIONAL COMMITMENT OF EMPLOYEE PERFORMANCE ON GOVERNMENT EMPLOYEES IN THE DPRD SECRETARIAT OF BALI PROVINCE, INDONESIA
}

\author{
Pradifta Ngurah Bagus Hendra*, Subudi Made \\ Faculty of Economic and Business, University of Udayana, Bali, Indonesia \\ *E-mail: ngurah.prap@gmail.com
}

\begin{abstract}
Performance is a key factor in organizational success. The better the performance produced by the employee, the faster the achievement of organizational goals. Employee performance will be maximal if it is able to manage stress, has commitment to its work and can divide the time between work roles and family roles. Performance factors are important aspects in managing human resources effectively and efficiently. This study aims to examine and analyze the effect of work-family conflict, work stress and organizational commitment on employee performance. Data collection was conducted by distributing questionnaires to 133 government employees at the DPRD Secretariat of the Province of Bali. This study uses saturated samples by distributing questionnaires to 133 employees as respondents. The data analysis technique used is path analysis. The results showed that work-family conflict directly had a significant negative effect on organizational commitment. Job stress has a significant negative direct effect on organizational commitment. Work-family conflict directly has a significant negative effect on employee performance. Job stress has a significant negative direct effect on employee performance. Whereas organizational commitment has a significant positive direct effect on organizational commitment.
\end{abstract}

\section{KEY WORDS}

Work-family conflict, work stress, organizational commitment, employee performance.

Bali Provincial DPRD Secretariat is a political institution that has the task of controlling and supervising the administration in accordance with the principle of regional autonomy. The DPRD Secretariat has a role to support the smooth implementation of the tasks and functions of DPRD members. its duties, including from the technical and operational side.

Employees in the Bali Provincial DPRD Secretariat are 133 employees led by the DPRD secretary. Governor Regulation Number 117 of 2016 The duties and functions of the DPRD secretary through the board secretary are 1) Implementation of DPRD secretariat administration, 2) Implementation of DPRD financial administration, 3) Facilities of DPRD meeting activities, 4) Provision and coordination of experts needed by DPRD, 5) Implementation the task of service to the DPRD and other functions provided by the governor in relation to their duties and functions.

In order to support the running of the tasks and functions of the DPRD secretariat in facilitating Bali Provincial DPRD Members, a RENJA was formulated or the Bali Provincial DPRD Secretariat Work Plan. Renja is a one-year plan that contains programs and activities as well as targets and targets set. The Work Plan of the DPRD Secretariat consists of 7 Programs 19 activities.

Civil servants and non-civil servants at the Bali Provincial DPRD Secretariat must have a good performance to achieve the Work Plan (Renja), because the better the level of performance realization in activities and programs that have been arranged in the Work Plan (Renja) the better the performance civil servants and non civil servants in facilitating the duties and functions of the members of the Bali Provincial DPRD. Civil servants and non-civil servants have the obligation to carry out work plans in the DPRD secretariat of the Province of Bali in accordance with Governor Regulation No.117 of 2016 concerning the position, organizational structure, duties and functions and work procedures of the Bali Provincial DPRD secretariat. 
The performance of civil servants and non-civil servants must be optimal in supporting and facilitating the Work Plan (Renja) because the more optimal performance of civil servants and Non-civil servants at the DPRD Secretariat of the Province of Bali will support the performance of Bali Provincial DPRD members in implementing legislative functions, budget functions, and supervisory functions. Civil servants and non-civil servants at the Bali Provincial DPRD Secretariat must have a strong commitment to achieving the Work Plan. The civil servants and non-civil servants are paid by the government and employees should have emotional ties and strong moral responsibility towards the organization and have a strong sense of ownership towards the achievement of the work plan in the DPRD Secretariat of the Province of Bali.

Table 1 - Achievement of Performance Services at the Bali Provincial DPRD Secretariat in 2015/2019

\begin{tabular}{|c|c|c|c|c|c|c|}
\hline \multirow[t]{2}{*}{ No } & \multirow[t]{2}{*}{ Indicator } & \multirow{2}{*}{$\begin{array}{c}\text { Target / Standard } \\
\text { Number / Value }\end{array}$} & \multicolumn{2}{|c|}{ SKPD Target } & \multicolumn{2}{|c|}{$\begin{array}{c}\text { Realization of } \\
\text { Achievement }\end{array}$} \\
\hline & & & Year & Target & Year & Realization \\
\hline (1) & (2) & (3) & $(4)$ & $(5)$ & $(6)$ & $(7)$ \\
\hline \multirow{5}{*}{1} & \multirow{5}{*}{$\begin{array}{c}\text { DPRD Member Satisfaction Rate Percentage } \\
\text { of Service Achievement of Bali Provincial } \\
\text { DPRD Secretariat }\end{array}$} & \multirow{5}{*}{$100 \%$} & 2015 & $100 \%$ & 2015 & $85 \%$ \\
\hline & & & 2016 & $100 \%$ & 2016 & $88 \%$ \\
\hline & & & 2017 & $100 \%$ & 2017 & $91 \%$ \\
\hline & & & 2018 & $100 \%$ & 2018 & $89 \%$ \\
\hline & & & 2019 & $100 \%$ & 2019 & - \\
\hline
\end{tabular}

Source: Bali Provincial DPRD Secretariat (2018).

Employees who are committed to their organization tend to be better than employees who are less committed (Jafri and Lhamo, 2013). Broadly speaking, employees who are committed to the organization will be more comfortable and accept organizational goals. Providing added value from employees that is shown through productivity and proactivity in every organizational goal (Ahmad and Roslan, 2016). The commitment and performance of civil servants and non-civil servants at the DPRD Secretariat is also influenced by workfamily conflict. Work-family conflict occurs when there is a mismatch between the demands of family and work roles. Increased awareness of conflicts between roles experienced by employees when they try to balance the demands of work and family roles, where this conflict can lead to negative consequences such as poor performance (Ajala, 2017).

Civil servants and non-civil servants at the Bali Provincial DPRD Secretariat cannot share the roles between work roles and family roles when problems with the family or family care responsibilities often have an impact on their behavior at work. Job stress according to Velnampy and Aravinthan (2013) is a pattern of emotional, cognitive, behavioral and psychological reactions that are detrimental to aspects of the organization. Civil servants and non-civil servants at the Bali Provincial DPRD Secretariat are vulnerable to stress experienced in carrying out daily tasks.

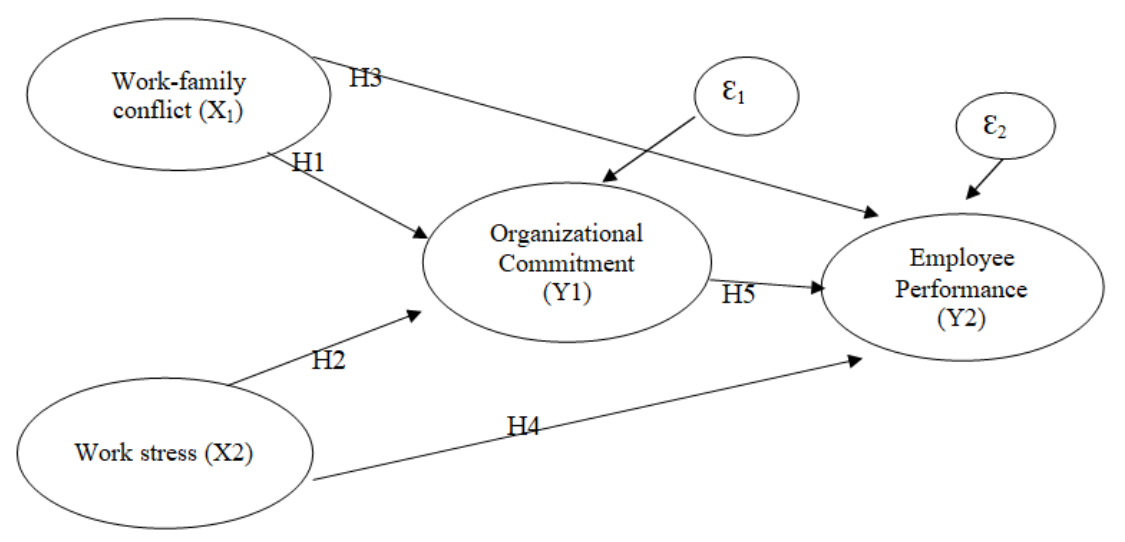

Figure 1 - Framework of study 
Based on the phenomenon that occurred at the Bali Provincial DPRD Secretariat described above and the results of previous research and theoretical basis with conditions at the DPRD Secretariat of Bali Province illustrate the gap between normative and positive conditions, the research and opinions of experts and theories above that employee performance is influenced by organizational commitment, work-family conflict and work stress. Referring to the results of the assessment that has been described, the following hypothesis is formulated:

- H1: Work-Family Conflict has a significant negative effect on organizational commitment;

- H2: Job stress has a significant negative effect on organizational commitment;

- H3: Work-family conflict has a significant negative effect on employee performance;

- H4: Job stress has a significant negative effect on employee performance;

- H5: organizational commitment has a significant positive effect on employee performance.

Geroda and Puspitasari (2017) work-family conflict and organizational commitment have a negative relationship; this means that the more conflicts between work and family experience, the organizational commitment will decrease. Ahmad and Roslan (2016) employees with low work stress will have high commitment and vice versa, high organizational commitment will affect productivity. The result is work stress has a negative effect on organizational commitment. Asfahyadin et al. (2017) the results of the study prove that work-family conflict has a negative effect on performance because the higher the conflict between work and family, the employee's performance will decrease. Nart and Batur (2013) stated that job stress negatively affected performance. Irefin and Mechanic (2014) that organizational commitment has a significant positive effect on performance.

\section{METHODS OF RESEARCH}

This study categorized as associative research is causal to know the relationship of two or more variables. The population in this study were all civil servants and non-civil servants at the Bali Provincial DPRD Secretariat of 133 people. The census method is used in determining the sample because all populations are sampled.

Confirmatory factor analysis (CFA) and path analysis (Path Analysis) techniques were used in this study. CFA is used to estimate measurement models and test unidimensionality of exogenous and endogenous constructs. The relationship between research variables is work-family conflict, work stress and organizational commitment to employee performance.

\section{RESULTS AND DISCUSSION}

The questionnaire was distributed to government officials, namely civil servants and non-civil servants in the Secretariat of the DPRD in the Province of Bali, amounting to 133 people with the number of respondents set. The questionnaires that were distributed were all complete and good again, and feasible to be processed and analyzed. Furthermore, the characteristics data of respondents are presented according to the table 2.

Indicator value in work-family variable conflict equal to or more than 0.5 . Time-based conflict, Strain-based conflict, Behavior-based conflict of all indicators strongly formed workfamily conflict variables.

Work-family conflict variables with indicators of behavior-based conflict with a value of 0.709 are the highest indicators forming work-family conflict variables, this means that family problems often make employees behave emotionally in the office and vice versa workplace problems affect employees' emotional behavior at home. The highest mean value in the strain-based conflict indicator was 3.92. This means that the tension in the workplace often disrupts family harmony as well as the disharmony in the family disrupts employee performance at the DPRD Secretariat of the Province of Bali.

The indicator value in the work stress variable is more than 0.5 . The indicator of workload, pressure, conflict, role ambiguity of all strong indicators form work stress variables. 
Table 2 - Characteristics of Respondents

\begin{tabular}{|c|c|c|c|c|c|}
\hline No & Characteristic & & Category & Total (Person) & Percentage (\%) \\
\hline \multirow[t]{5}{*}{1} & Age & $A$ & $20-30$ & 50 & 38 \\
\hline & & $\mathrm{B}$ & $31-40$ & 42 & 31 \\
\hline & & $\mathrm{C}$ & $41-50$ & 32 & 24 \\
\hline & & $\mathrm{D}$ & $>50$ & 9 & 7 \\
\hline & Total & & & 133 & 100 \\
\hline \multirow[t]{3}{*}{2} & Gender & $A$ & Man & 64 & 48 \\
\hline & & $B$ & Women & 69 & 52 \\
\hline & Total & & & 133 & 100 \\
\hline \multirow[t]{6}{*}{3} & Pendidikan & $A$ & Elementary school & 11 & 8 \\
\hline & & $\mathrm{B}$ & Junior high school & 28 & 21 \\
\hline & & $C$ & High school & 26 & 20 \\
\hline & & $\mathrm{D}$ & Bachelor degree & 51 & 38 \\
\hline & & $E$ & Master degree & 17 & 13 \\
\hline & Total & & & 133 & 100 \\
\hline \multirow[t]{6}{*}{4} & Years of service & $\mathrm{A}$ & 2 years $<$ & 21 & 16 \\
\hline & & $\mathrm{B}$ & $2-5$ years & 55 & 41 \\
\hline & & C & $6-10$ years & 44 & 33 \\
\hline & & $\mathrm{D}$ & $11-15$ years & 12 & 9 \\
\hline & & $\mathrm{E}$ & 15 years $>$ & 1 & 1 \\
\hline & Total & & & 133 & 100 \\
\hline
\end{tabular}

Source: Results of processing research data.

Table 3 - Factor Analysis and Mean Values

\begin{tabular}{|c|c|c|}
\hline Indicator & Factor Value & Mean \\
\hline time-based conflict & 0,634 & 2,71 \\
\hline strain-based conflict & 0,657 & 3.92 \\
\hline behavior-based conflict & 0,709 & 3.15 \\
\hline
\end{tabular}

Source: Results of processing research data.

Table 4 - Factor Analysis and Mean Values

\begin{tabular}{|c|c|c|}
\hline Indicator & Factor Value & Mean \\
\hline Workload & 0,685 & 3.02 \\
\hline Pressure & 0,817 & 2.71 \\
\hline Conflict & 0,538 & 2.92 \\
\hline Role Ambiguity & 0,537 & 2.72 \\
\hline
\end{tabular}

Source: Results of processing research data.

Job stress variables with a Pressure indicator with a value of 0.685 are the highest indicators forming work stress variables; this means that inadequate time in carrying out tasks and targets that are too high causes employees to experience stress. The highest mean value on the workload indicator is 3.02 . This means that the workload of employees is felt to be too high and sometimes the work provided is not in accordance with the expertise when working in the DPRD Secretariat of the Province of Bali.

Table 5 - Factor Analysis and Mean Values

\begin{tabular}{|c|c|c|}
\hline Indicator & Factor Value & Mean \\
\hline Affective Commitment & 0,632 & 3.37 \\
\hline Continuance Commitment & 0,592 & 3.27 \\
\hline Normative Commitment & 0,577 & 3.18 \\
\hline
\end{tabular}

Source: Results of processing research data.

The variable organizational commitment with affective commitment indicators with a factor value of 0.632 is the highest indicator forming the variable organizational commitment, this means that how an employee feels emotionally bound to the organization. The highest mean 
value on the affective commitment indicator is 3.37. This means that employees feel they have an organization in the DPRD Secretariat of the Province of Bali.

Table 6 - Factor Analysis and Mean Values

\begin{tabular}{|c|c|c|}
\hline Indicator & Factor Value & Mean \\
\hline Quantity & 0,732 & 3,32 \\
\hline Quality & 0,521 & 3,32 \\
\hline Punctuality & 0,515 & 3,40 \\
\hline Presence & 0,522 & 3,35 \\
\hline Cooperation & 0,534 & 3,37 \\
\hline
\end{tabular}

Source: Results of processing research data.

Employee performance variables with quantity indicators with a factor value of 0.732 are the highest indicators forming employee performance variables, this means that how an employee always completes tasks that have become a responsibility in a certain period of time properly. The highest mean value on the indicator of timeliness is 3.40 . This means that employees can always complete tasks given in a timely manner at the DPRD Secretariat of the Province of Bali.

Data testing is used by path analysis (path analysis), which is to test the patterns of relationships between variables studied so that it can show direct or indirect effects of hypothesized variables. This path analysis is carried out by the following steps.

$$
R_{m}^{2}=1-\left(\mathrm{Pe}_{1}\right)^{2}\left(\mathrm{Pe}_{2}\right)^{2}=0,909
$$

Based on the results of the calculation of the total determination coefficient, it can be stated that the diversity of data that can be explained by the model is 0.909 or 90.9 percent in other words the information contained in the data is 90.9 percent can be explained in the model, while the rest is 9.1 percent is explained by other variables (not in the model) and errors.

In theory trimming, non-significant pathways are discarded. Test the validity of the path coefficients on the path for direct influence is the same as in the regression by looking at the level of significance $(\mathrm{sig})<0.05$. The following is the level of significance of each variable.

Substructure 1:

$$
X 1=0.028<0.05 ; X 2=0,000<0.05
$$

Substructure 2:

$$
\mathrm{X} 1=0,000<0.05 ; \mathrm{X} 2=0,000<0.05 ; \mathrm{Y} 1=0.013<0.05
$$

Based on these results it can be stated that all the lines built in the previous construct model are declared valid.

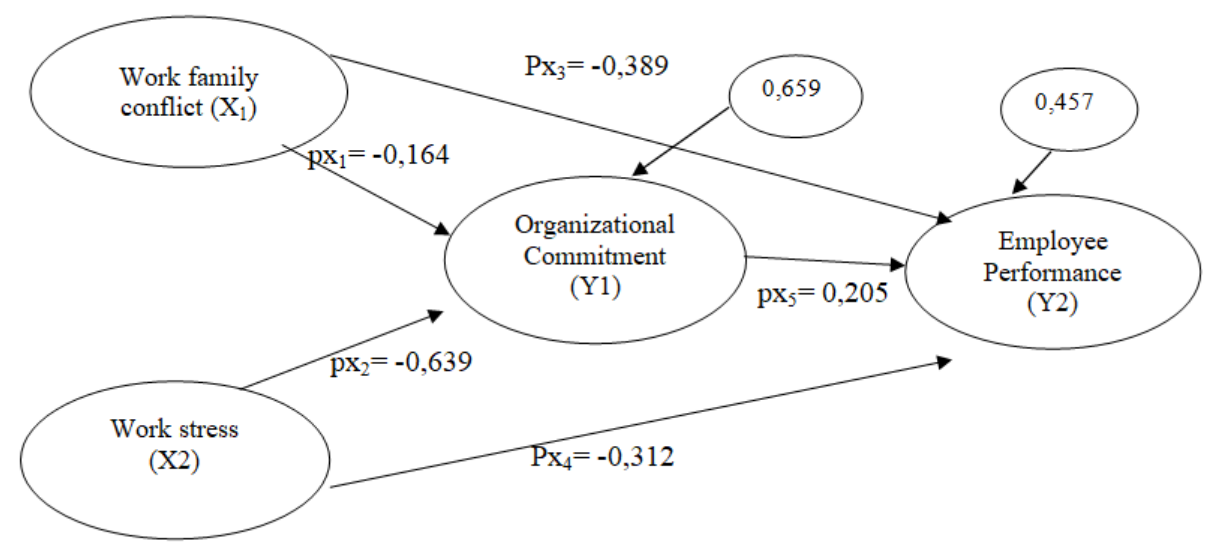


Table 7 - Results of Path Analysis Coefficients

\begin{tabular}{|l|c|c|c|c|}
\hline \multicolumn{1}{|c|}{ Contributions between Variables } & $\begin{array}{c}\text { Path Coefficient } \\
\text { (Beta) }\end{array}$ & t Value & $\begin{array}{c}\text { Sig. } \\
\text { value }\end{array}$ & \begin{tabular}{c} 
Information \\
\hline $\begin{array}{l}\text { Work-Family Conflict (X1) against Organizational } \\
\text { Commitment (Y1) }\end{array}$
\end{tabular} \\
\hline $\begin{array}{l}\text { Work Stress (X2) on Organizational Commitment } \\
\text { (Y1) }\end{array}$ & $-0,164$ & -2.215 & 0,028 & $\begin{array}{c}\text { Negative } \\
\text { Significant }\end{array}$ \\
\hline $\begin{array}{l}\text { Work-Family Conflict (X1) on Employee } \\
\text { Performance (Y2) }\end{array}$ & $-0,389$ & -8.633 & 0,000 & $\begin{array}{c}\text { Negative } \\
\text { Significant }\end{array}$ \\
\hline Job Stress (X2) on Employee Performance (Y2) & $-0,312$ & -3.604 & 0,000 & $\begin{array}{c}\text { Negative } \\
\text { Significant }\end{array}$ \\
\hline $\begin{array}{l}\text { Organizational Commitment (Y1) to Employee } \\
\text { Performance (Y2) }\end{array}$ & 0,205 & 2.507 & 0,015 & $\begin{array}{c}\text { Negative } \\
\text { Significant }\end{array}$ \\
\hline
\end{tabular}

Source: Results of processing research data.

The direct effect of work-family conflict on organizational commitment. The calculation results show that Beta -0.164 with a value of $t$ count -2.215 with a significance level of 0.028 smaller than the probability value of 0.05 or $0.028<0.05$, the path analysis coefficient is negative significant, so work-family conflict has a significant negative effect on commitment organizational. Significant negative influences can be interpreted, conflicts between roles experienced by employees have a negative impact on employee commitment in completing work.

The direct effect of work stress on organizational commitment. The results of the calculation show that Beta -0.639 with the value of $t$ count -8.633 with a significance level of 0,000 smaller than the probability value of 0.05 or $0,000<0.05$, the path analysis coefficient is significantly negative, so work stress has a significant negative effect on organizational commitment. Significant negative influence can be interpreted, the pressure at work and conflict with family has a negative impact on the commitment of employees in completing work.

The effect of direct work-family conflict on employee performance. The calculation results in the Table show that Beta $-0,389$ with the value of t count $-5,532$ with a significance level of 0,000 smaller than the probability value of 0,05 or $0,000<0,05$, the path analysis coefficient is negative significant, so work-family conflict has a significant negative effect on employee performance. Significant negative influence can be interpreted with family problems that have a negative impact on employee performance in the workplace.

The direct effect of work stress on employee performance. The results of calculations in the Table show that Beta -0.312 with the value of $t$ count -3.604 with a significance level of 0,000 smaller than the probability value of 0.05 or $0,000<0.05$, the path analysis coefficient is significantly negative, so work stress has a significant negative effect on performance employee. Significant negative influence can be interpreted that stress experienced by employees has a negative impact on employee performance in the workplace.

Direct influence of organizational commitment on employee performance. The calculation results in the Table show that Beta is 0.205 with a value of $2.507 \mathrm{t}$ with a significance level of 0,000 smaller than the probability value of 0.05 or $0,000<0.05$, the path analysis coefficient is significantly positive, so organizational commitment has a significant positive effect on employee performance. Significant positive influences can be interpreted as attachments; emotional feelings and sense of employee ownership of the organization have a positive impact on the performance of employees in the workplace.

\section{DISCUSSION OF RESULTS}

Work-family conflict has a significant negative effect on organizational commitment. These results indicate that role conflict experienced by employees in the family or work influences emotional behavior that adversely affects the commitment of employees at work. Work-family conflict was measured through time-based conflict, strain based-conflict, behavior-based conflict. 
Based on employee ratings, work-family conflict makes employees experience stress and emotional causes caused by conflict in the workplace or in the family. Employees find it difficult to divide the time between work time and family time, workplace tensions often interfere with family harmony and conversely tension in the family often affects performance. Problems faced by employees in the workplace often have an impact on emotional behavior in the family or vice versa. So as to make the organizational commitment of employees to be low.

The results of Geroda and Puspitasari (2017) work-family conflict and organizational commitment have a negative relationship; this means that the more conflict between work and family experience the organizational commitment will decrease. Jenitta (2013) states that work-family conflict has a negative effect on affective commitment, ongoing commitment. Hatam et al. (2015) stated that work-family conflict had a negative effect on organizational commitment.

Job stress has a significant negative effect on organizational commitment. This shows that stress experienced by employees often causes stress or frustration in carrying out daily tasks. Job stress is measured by workload, pressure, conflict, role ambiguity.

Based on employee appraisal, excessive workload and sometimes the work provided is not in accordance with expertise, less time in carrying out work and targets that are too high, conflict with family and coworkers, my income is not in accordance with the work done. Stress makes employee organizational commitment low.

The research conducted by Bhatti et al. (2016) by examining the banking sector in Pakistan with the results of work stress negatively affects organizational commitment, where work stress is the main cause of decreased commitment. Nart and Batur (2013) in their study stated that work stress has a negative impact on organizational commitment. Ahmad and Roslan (2016) state that employees who do not experience stress will have high commitment and vice versa. High organizational commitment will affect productivity. The result is stressful work that has a negative effect on organizational commitment.

Work-family conflict has a significant negative effect on employee performance. These results indicate that family role conflict and work affect emotional behavior which adversely affects employee performance. Work-family conflict was measured through time-based conflict, strain based-conflict, behavior-based conflict.

Based on employee ratings, work-family conflict makes employees experience stress and emotional causes caused by conflict in the workplace or in the family. Employees find it difficult to divide the time between work time and family time, tensions in the workplace often interfere with family harmony and conversely tension in the family often affects performance. Problems faced by employees in the workplace often have an impact on emotional behavior in the family or vice versa. So as to make employee performance low.

Karakas and Sahin Research (2017) at a hotel management in the western black sea province in Turkey that work-family conflict had a negative effect on performance. Warokka and Febrillia (2015) examined four major banks in Indonesia that the negative relationship between work-family conflict and performance. Ajala (2017) studied mothers who worked in government hospitals in the Nigerian town of Nigeria that work-family conflict had a significant negative effect on performance.

Job stress has a significant negative effect on employee performance. This shows that stress experienced by employees often causes stress or frustration in carrying out daily tasks. Job stress is measured by workload, pressure, conflict, role ambiguity.

Based on employee appraisal, excessive workload and sometimes the work provided is not in accordance with expertise, time is lacking in carrying out work and targets are too high, conflict with family and coworkers, income is not in accordance with the work done. Stress makes employee performance low.

Research conducted by Arbabisarjou et al. (2013); Ratnawat and Jha., (2014) work stress is a current organizational problem that provides low performance where work stress has a negative effect on performance. The same results from the study of Banerjee and Mehta (2016) where job stress as the main contributor to stress levels, the effect of stress proved to be able to reduce performance. 
Organizational Commitment has a significant positive effect on employee performance. This shows that the assurance of employees in accepting the values adopted by the organization has a strong impact on the achievement of the organization. Organizational commitment is measured by affective commitment, continuance commitment, normative commitment.

Based on employee ratings, employees feel an emotional bond, feel an attachment to the organization, little choice if they leave the organization, their lives will be disrupted, employees feel they have a moral obligation to the organization and the organization has provided something valuable to employees. So that organizational commitment makes employee performance good.

Research Fu \& Deshpande (2014) examined an insurance company in China that stated organizational commitment had a positive influence on performance, reinforced by the results of the study of Triwahyuni and Ekowati (2017) that organizational commitment had a significant influence on performance. Irefin and Mechanic (2014) examined the effect of employee commitment on coca cola companies in Nigeria, where organizational commitment has a positive effect on performance.

Work-family conflict has a significant negative effect on employee performance through organizational commitment. These results indicate that role conflict experienced by employees in the family or work affects emotional behavior that adversely affects commitment, due to the low commitment caused by conflict in the family environment or work environment which adversely affects employee performance.

Work-family conflict through time-based conflict, strain based-conflict, behaviour-based conflict make employees experience stress and emotional causes caused by conflict at work or in the family. Employees find it difficult to divide the time between work time and family time, workplace tensions often interfere with family harmony and conversely family tensions often affect performance, problems faced by employees at work often affect emotional behavior in the family or vice versa. So as to make employee commitment to be low this has an impact on poor performance.

Previous research conducted by Cristine (2010), Harijanto (2013) and Geroda (2017) suggested that organizational commitment does not have a significant role as an intervening variable between work-family conflict on performance.

Job stress has a significant negative effect on employee performance through organizational commitment. This shows that the stress experienced by employees often causes stress or frustration in carrying out daily tasks that are very strong affecting organizational commitment that adversely affects performance.

Job stress on workload, pressure, conflict, role ambiguity contributes negatively where the workload is excessive and sometimes the work given is not in accordance with expertise, time is less in carrying out work and targets are too high, conflict with family and colleagues income that is not in accordance with the work performed. Stress makes employees' commitment low, with implications for low performance.

Previous research conducted by Nursyami (2012), and Masihabadi et al., (2015) said that work stress through organizational commitment had a negative impact on employee performance.

Based on the results of research conducted by the authors there are implications that can be generated from this study. First, in the work-family conflict variable, the results showed that the three indicators of time-based conflict, strain-based conflict, behavior-based conflict had relatively good average values, which meant that the time spent working prevented the time needed to work, fulfil family obligations. Employees find it difficult to divide the time between work and family. Tensions experienced by employees often affect or disrupt family harmony and disharmony in the family often disrupts employee performance. Family problems faced by employees cause emotional behavior in the workplace and family problems faced by employees causing emotional behavior in the family where every government employee should be able to professionally divide roles between work and family and commit and perform professionally to achieve successful work plans (Renja). The lowest value lies in a time-based conflict where the time used at work blocks the time needed 
to fulfill family obligations, find it difficult to divide the time between work and family because it requires professional work and evaluation within the government of the Bali Provincial DPRD Secretariat.

Second, in the work stress variable, the results show that the four indicators, namely workload, pressure, conflict, ambiguity role, have an average score that is quite good. This means that employees feel the workload given is excessive. Employees feel the time at work is inadequate, the job target is too high, problems with family and coworkers often hamper performance. The work done is different from the analysis of the position and the income received is not in accordance with the job. But the lowest value lies in the workload of the work performed by employees often not in accordance with expertise so that it often causes stress, this should be a concern for government employees in the DPRD Secretariat of the Province of Bali.

Third, in the organizational commitment variable, the results of the three indicators are affective commitment, continuance commitment, and normative commitment. The three average values of these indicators are quite good where employees have an emotional bond. Having a sense of belonging and few choices left the company. There are consequences if leaving the organization and organization has provided something of value. have a moral obligation to the organization but the lowest value lies in continuance commitment where the organization must be able to maintain and foster a good moral sense among fellow workers so that organizational goals can be achieved at the DPRD Secretariat of the Province of Bali.

Fourth, in the employee performance variable the results of the five indicators are obtained, namely quality, quantity, timeliness, attendance and cooperation. The five average values of these indicators are quite good, where employees can complete tasks in accordance with predetermined targets, employees are able to complete tasks that are the responsibility in a certain period of time. Employees can complete tasks that have become responsibilities with satisfactory results and work results are no doubt because they are in accordance with the standards. Employees never delay work that has become their responsibility. Present on time at work and present to work in accordance with existing regulations. Can foster collaboration with colleagues and work well when working in teams. But the lowest value lies in quality, there needs to be a re-evaluation of the workload of each employee so that the targets that have been determined can be achieved by government employees in the DPRD Secretariat of the Province of Bali.

\section{CONCLUSION AND SUGGESTIONS}

Work-family conflict has a significant negative effect on organizational commitment which means that employees are very susceptible to conflict with family or work environments that suffer badly from harmony in the workplace and family. When experiencing conflict in the family or work environment often emotional behavior can be seen as a result of low organizational commitment.

Job stress has a significant negative effect on organizational commitment which means that the workload charged at work is too high. The work provided must be in accordance with expertise. Working time with work targets must be adjusted to be balanced. Conflicts with family or with colleagues often affect performance. The work done is often not in accordance with the analysis of the position and the income provided must be in accordance with the job.

Work-family conflict has a significant negative effect on employee performance, which means that employees are very vulnerable to experiencing conflict with family or conflict in the work environment that has a negative impact on family life and work harmony. Employees when experiencing conflict both in their family or work environment often behave emotionally so that it has a negative impact on employee performance.

Job stress has a significant negative effect on employee performance which means that the workload charged at work is too high. The work provided must be in accordance with expertise. Work time and work target must be balanced. conflicts with family or with colleagues often affect performance. The work carried out is often not in accordance with the 
analysis of the position and the income provided must be in accordance with the workload in order to be able to improve employee performance.

Organizational Commitment has a significant positive effect on employee performance which means that employees have an emotional bond and a sense of belonging. Employees have little choice to leave the organization and there are consequences if they leave the organization. The organization has provided something valuable for employees. Employees have a moral obligation to the organization so that it has a positive impact on employee performance.

Based on the results of this study, some suggestions that can be used as consideration in determining future policies, especially those related to work-family conflict, work stress, organizational commitment and employee performance.

In anticipating the impact of work-family conflict so that it is better for a civil servant and non-civil servant in the Regional Representatives Council of Bali Province to be able to divide roles between work and family so that each role can run in harmony. Being able to manage relationships that are good in the family environment or in the workplace so as to foster positive energy in each role, which directly impacts on harmony in the family and optimal performance in the workplace.

In anticipating the impact of work stress, it is best to build a harmonious relationship with colleagues in order to run smoothly in carrying out daily tasks. Review the main tasks and functions so that every civil servant and non-civil servant workload is in accordance with their respective duties and employees no longer take excessive work and also employees are assigned according to their respective expertise in order to avoid stress.

In increasing organizational commitment the organization should be able to foster a sense of ownership and emotional ties and moral obligations in the DPRD Secretariat of Bali Province so that employees are willing to accept all the values adopted by the organization and are committed to achieving organizational goals.

In improving employee performance, the organization in the Bali Provincial DPRD Secretariat should pay attention to aspects of work-family conflict, work stress and aspects of organizational commitment to improve employee performance and operationally each employee must be able to maintain harmonious relationships in the family environment. positive in the work environment. Operationally the work target for each employee must be adjusted to the time at work so that there is no fatigue and stress because the workload or target is too high due to limited time and each employee must be adjusted to the main tasks and functions in order to improve performance employee.

\section{REFERENCES}

1. Arbabisarjou, A., Ajdari, Z., Omeidi, K., \& Jalalinejad, R. (2013). The relationship between Job stress and performance among the hospitals Nurses. World Sci J, 1, 181-8.

2. Ajala, E. M. (2017). Work-family-conflict and family-work-conflict as correlates of job performance among working mothers: implications for industrial social workers. African Journal of Social Work, 7(1), 52-62.

3. Ahmad, S. O., \& Roslan, N. F. (2016). Relation between Job Stress and Organizational Commitment among Public Servant in Pontian, Johor. International Journal of Business, Economics and Law, 10(2), 1-6

4. Bhatti, M. H., Bhatti, M. H., Akram, M. U., Hashim, M., \& Akram, Z. (2016). Relationship between job stress and organizational commitment: An empirical study of banking sector. E3 Journal of Business Management and Economics, 7(1), 029-037.

5. Banerjee, S., \& Mehta, P. (2016). Determining the antecedents of job stress and their impact on job performance: A study among faculty members. IUP Journal of Organizational Behavior, 15(2), 7.

6. Christine, W. S., Oktorina, M., \& Mula, I. (2011). Pengaruh konflik pekerjaan and konflik keluarga terhadap kinerja dengan konflik pekerjaan keluarga sebagai intervening variabel (studi pada dual career couple di Jabodetabek). Jurnal Manajemen and Kewirausahaan, 12(2), 121-132. 
7. Dewi, I. G. A. M. (2012). Sopistikasi teori konflik pekerjaan-keluarga: Sebuah kajian kritis. Piramida.

8. Fu, W., \& Deshpande, S. P. (2014). The impact of caring climate, job satisfaction, and organizational commitment on job performance of employees in a China's insurance company. Journal of Business Ethics, 124(2), 339-349.

9. Hatam, N., Jalali, M. T., Askarian, M., \& Kharazmi, E. (2016). Relationship between family-work and work-family conflict with organizational commitment and desertion intention among nurses and paramedical staff at hospitals. International journal of community based nursing and midwifery, 4(2), 107.

10. Irefin, P., \& Mechanic, M. A. (2014). Effect of employee commitment on organizational performance in Coca Cola Nigeria Limited Maiduguri, Borno state. Journal of Humanities and Social Science, 19(3), 33-41

11. Jenitta, J. N., \& Periyathampy, E. (2013). An Impact of Work Family Conflict on Organizational Commitment: A Study of Staff Members at People'S Bank in Trincomalee District.

12. Masihabadi, A., Rajaei, A., Shams Koloukhi, A., \& Parsian, H. (2015). Effects of stress on auditors' organizational commitment, job satisfaction, and job performance.

13. Nart, S., \& Batur, O. (2014). The relation between work-family conflict, job stress, organizational commitment and job performance: A study on Turkish primary teachers. European Journal of Research on Education, 2(2), 72-81.

14. Ratnawat, R. G., \& Jha, P. C. (2014). Impact of job related stress on employee performance: a review and research agenda. Journal of Business and Management, 16(11), 1-16.

15. Geroda, M. K. B., \& Puspitasari, E. (2017, June). The Impact Of Work-Family Conflict Toward Job Performance-the Case Of External Auditor. In The 3rd PIABC (Parahyangan International Accounting and Business Conference.

16. Jafri, M. H., \& Lhamo, T. (2013). Organizational commitment and work performance in regular and contract faculties of Royal University of Bhutan. Journal of Contemporary Research in Management, 8(2), 47.

17. Triwahyuni, R., \& Ekowati, V. M. (2017). The Effect of Employee Satisfaction on Employees Performance Trhough Organizational Commitment.

18. Velnampy, T., \& Aravinthan, S. A. (2013). Occupational Stress and Organizational Commitment in Private Banks: A Sri Lankan Experience.

19. Warokka, A., \& Febrilia, I. (2015). Work-Family Conflict and Job Performance: Lesson from a Southeast Asian Emerging Market. Journal of Southeast Asian Research, 46(6), $1-14$. 